\title{
Analyzing Factors that Affect Rice Import Volume in Indonesia
}

\author{
Dr. Anita Permatasari, M.M., Ak. \\ Catholic University of Darma Cendika
}

\begin{abstract}
There are four factors that can affect the volume of rice import in Indonesia, they are rice production, gross domestic production (PDB), rice consumption, and increasing population of Indonesian citizens. The study applies qualitative method. The data used in study is secondary data within years of research from 2014 to 2018. Independent variables in this study are rice production (PRODUKSI), gross domestic product (PDP), consumption of rice (KONSUMSI), total population of Indonesian citizens (PENDUDUK). The dependent variable in this study is rice import (IMPORT). The result of study reveals that production of rice (PRODUKSI), gross domestic product (PDP), riceconsumption (KONSUMSI), do not affect toward rice import from 2014 to 2018 period. Meanwhile, total population of Indonesian citizens (PENDUDUK) affect number of rice import in Indonesia from 2014 to 2018.
\end{abstract}

Keywords: rice production, gross domestic product, rice consumption, total population, and rice import.

DOI: $10.7176 / \mathrm{JESD} / 11-10-01$

Publication date:May $31^{\text {st }} 2020$

\section{Introduction}

Indonesia is an agrarian country, whereas most of its people occupation is farmer and plantation business. In 2016, office for national statistics of Indonesia (BPS) recorded that 31,47\% of Indonesian working performance is occupied by agriculture sector. Agriculture sector, in Indonesia, has important role in securing food supply for society. Thus, strategically, agriculture sector can create national food security that indirectly related to national defense. Food demands from society could be measured from the volume of rice that can be produced by agriculture sector. Rice is one of basic need for Indonesian citizens.

Agriculture sector is expected to be able to cover all food demands from society, thus government will stop importing rice from another country. In fact, government still performs import from other countries. One of reason is to secure the food supply in Indonesia (Christianto, 2013) because increasing number of populations will also increase food demand. Government also expects to be able to cover all demands of food from its quality, quantity, and security (Prabowo, 2010).

Development of rice import volume of Indonesia from 2010 to 2016 is significantly high. Annually, Indonesia imported 912,81 tons of rice, it means that the volume is increasing 49,2\% each year. In 2015 , the imported rice volume is 861,63 ton each year. Mostly, Indonesia receive the food from Vietnam which is 509,374 tons or $59,12 \%$ from total import, it equals to US \$202,56 million (Statistics Office of Indonesia, 2018). According to statistics office of Indonesia, Indonesia imported rice mostly from Thailand as much as 795,600 ton, meanwhile imported rice from Vietnam is 767,181 ton, India exported its rice to Indonesia as much as 337,999 ton, imported rice from Pakistan is 310,990 ton, imported rice from China is 228,000 tons, and imported from another countries is 41,827 tons. Total imported rice by Indonesian government is $2.253,825$ ton. The number will decrease if Indonesia could perform rice self-sufficiency.

In one side, the higher volume of imported rice, the better food supply from society will be, in other hand, it will kill domestic rice production (Larassati, 2007). Uncontrolled volume of imported rice will result in negative impact which is wasteful use of national expenditure that can be used for another sector.

There are several factors that can affect the volume of rice import in Indonesia; they are rice production, gross domestic production (PDB), rice consumption, and increasing population of Indonesian citizens. The first factor is rice production. Increasing rice production which is periodically performed by government is expected to cover food demands among society. Increasing volume of domestic production is expected to lower rice importing action. It means that food supply is secured by domestic production, if domestic rice production is increased, it will lower volume of imported rice for Indonesia.

Second factor is gross domestic product (PDB). Increasing income of a country will increase the number of imported things and vice versa (Pakpahan, 2012). Gross domestic product (PDB) is a reflection of Indonesian income. The increasing number of gross domestic product will bring positive impact toward import. It can also become one of expenditure source.

Third factor is rice consumption. Consuming rice is the most basic need for Indonesian citizen. High demand of rice is not followed by high quality of rice. It is used by government as reason to perform rice import; it is faster and easier to import than waiting for harvest moon (Djunaedi, 2012).

Population is the fourth factor. Increasing population will affect importing action, because Indonesia is the fourth country who has highest density of population in the world. The more total population of citizens, the more 
possibility for government to import the food (Singgih, 2015). The increasing number of population could be controlled if government is able to control its population that will lower the volume of imported rice.

\section{Theoretical Framework}

\section{International trade theory}

In one word, international trade could be interpreted as a trade that commenced by two or more countries. International trade become important aspect for industry development of a country. There are several theories that become foundation of international trade which are Adam Smith and David Ricardo superiority comparative theory (Salvatore, 2014). Mercantilism theory was introduced in 17th and 18th century. It is stated that a country will gain profit from international trade, if the country is willing to sacrifice other countries. The theory suggested to limit the number of import, incentive for import action, and it is advisable for government to create a firm law for economic action.

Absolute superiority theory by Adam Smith stated that the trade between two countries is based on absolute superiority. Absolute superiority is possessed by a country who is more superiority toward others for a certain product within cheaper production cost, thus other countries who are less superior could trade goods with other countries. There are two ideas provided by Adam Smith theory which are division of labour and international specialization within efficient production.

Comparative superiority theory stated that international trade act is occurred as result of different comparative superiority between countries. Comparative superiority will be achieved by country that can mass produce a product within less cost compared to other country. David Ricardo law of comparative superiority becomes a basic for country to perform export and import (Salvatore, 2004).

\section{Demand theory}

Law demand stated that price and supply will be inversely proportional within ceteris paribus condition (Mallios, 2004). Ceteris paribus condition stated that the lower price will increase demand of the product, and the higher price will decrease demand for the product. Too expensive price of a product will make consumer to find better alternatives within more reasonable price, $($ Greco, 2005). It is different from products that have no alternatives or have no substitution products, then the products will only experience low demand (Mankiw, 2008). Because, the people who need it only lowering their demand.

\section{Import}

Import becomes one of international trade action that meant to receive packages of goods or commodities from other countries (Juniantara and Budhi 2012). Factors that triggered import, according to Krugman and Obsfeld (2010:124), are limited human and natural resource to process the materials into consumable goods, impossible goods or services to be produced by a country, and to supply up supply for future.

\section{Rice Import Policy}

Regulation and limitation of rice import is already governed by Indonesia. This policy is meant to control the price of rice, to protect consumer to be able to buy within reasonable price, meanwhile from farmer perspective is to receive a reasonable price for the goods that they had harvested. Rice import policy could be seen from kind and quality of imported rice. There are two kinds which are rice with medium and premium quality.

\section{Impact of Rice Import Policy}

Importing rice by government will trigger a long term negative impact for part of farmer. The farmer will suffer from decreasing income. Because, the buyer will be prefer to buy imported rice because of the quality. In one hand, there are several impacts that must be considered by government, one of them is the transforming plantation into industrial area that forced farmer to sell their land in order to build regency, office, or other industrial building. At the end, it will weaken the national food security.

\section{III.Research Procedure}

The study applies quantitative method and uses Statistical Package for Social Sciences (SPSS) to process the data. The data used in study is secondary data which are retrieved from 2014 to 2018 which is received from Bulog and statistics office of Indonesia. There are two research variables which are dependent and independent variable. The independent variables are rice production (Production), gross domestic product (PDP), consumption of rice (Consumption), total population of Indonesian citizens (Inhabitant). The dependent variable in this study is rice import (Import). 


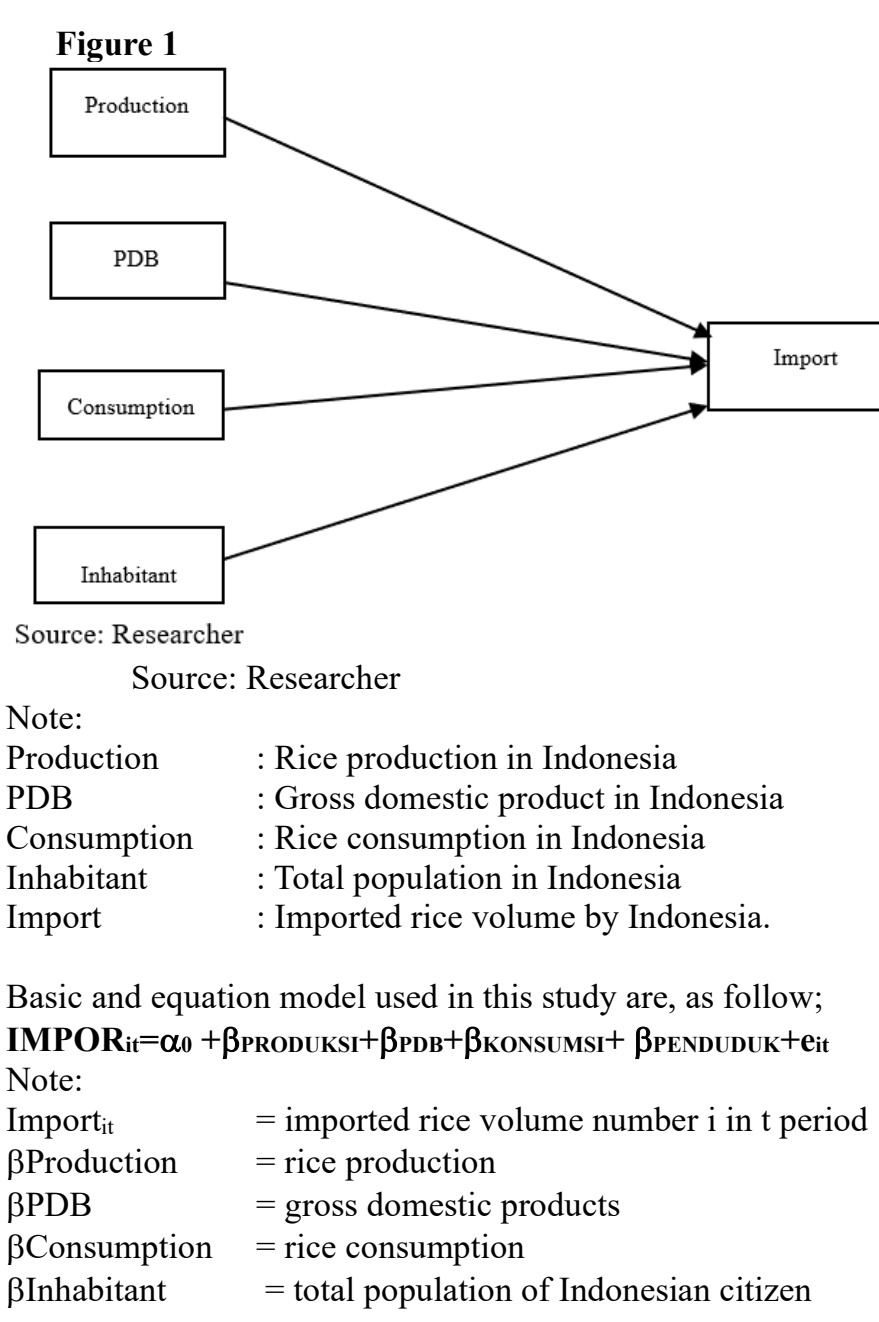

\section{IV.Finding and Discussion}

Table 1

Descriptive Statistics

\begin{tabular}{|l|l|l|l|l|l|}
\hline & $\mathrm{N}$ & Minimum & Maximum & Mean & Std. Deviation \\
\hline Production & 170 & 627.00 & 13633701.00 & 2294291.2235 & 3393358.44713 \\
PDB & 170 & 24042.00 & 2599174.00 & 374831.2765 & 537319.37442 \\
Consumption & 170 & 66.00 & 1003.00 & 104.6176 & 71.07335 \\
Inhabitant & 170 & 850.00 & 48684.00 & 7658.4529 & 10741.15214 \\
Import & 170 & 106001.00 & 41150361.00 & 3263554.3176 & 5631106.81113 \\
Valid N (listwise) & 170 & & & & \\
\hline
\end{tabular}

Source: Processed data by researcher

Table 1 displayed descriptive statistics of research variables from 2014 to 2018 research period within research sample acquired from all provinces of Indonesia that are 34 provinces in total. The provinces are displayed in table 2. 
Table 2

34 Provinces of Indonesia

\begin{tabular}{|c|c|}
\hline 1 & $\mathrm{ACEH}$ \\
\hline 2 & NORTH SUMATERA \\
\hline 3 & WEST SUMATERA \\
\hline 4 & RIAU \\
\hline 5 & JAMBI \\
\hline 6 & SOUTH SUMATERA \\
\hline 7 & BENGKULU \\
\hline 8 & LAMPUNG \\
\hline 9 & BANGKA BELITUNG ISLANDS \\
\hline 10 & RIAU ISLANDS \\
\hline 11 & SPECIAL CAPITAL REGION OF JAKARTA \\
\hline 12 & WEST JAVA \\
\hline 13 & CENTER JAVA \\
\hline 14 & SPECIAL REGION OF YOGYAKARTA \\
\hline 15 & EAST JAVA \\
\hline 16 & BANTEN \\
\hline 17 & BALI \\
\hline 18 & WEST NUSA TENGGARA \\
\hline 19 & EAST NUSA TENGGARA \\
\hline 20 & WEST KALIMANTAN \\
\hline 21 & CENTER KALIMANTAN \\
\hline 22 & SOUTH KALIMANTAN \\
\hline 23 & EAST KALIMANTAN \\
\hline 24 & NORTH KALIMANTAN \\
\hline 25 & NORTH SULAWESI \\
\hline 26 & CENTER SULAWESI \\
\hline 27 & SOUTH SULAWESI \\
\hline 28 & SOUTHEAST SULAWESI \\
\hline 29 & GORONTALO \\
\hline 30 & WEST SULAWESI \\
\hline 31 & MALUKU \\
\hline 32 & NORTH MALUKU \\
\hline 33 & WEST PAPUA \\
\hline 34 & PAPUA \\
\hline
\end{tabular}

Source: Statistic center of Indonesia (BPS), 2008

Table 3

Result of $F_{\text {count }}$

\begin{tabular}{|c|c|c|c|c|c|}
\hline Model & Sum of Squares & $\mathrm{df}$ & Mean Square & $\mathrm{F}$ & Sig. \\
\hline Regression & 3604269196615477.000 & 4 & 901067299153869.200 & 84.734 & $.000^{\mathrm{b}}$ \\
\hline 1 Residual & 1754613305580161.000 & 165 & 10634020033819.158 & & \\
\hline Total & 5358882502195638.000 & 169 & & & \\
\hline
\end{tabular}

Source: Processed data by researcher

a. Dependent Variable: Import

b. Predictors: (Constant), Inhabitant, Comsumptio, PDB, Production

The result of R2 displayed in table 4 reveals the impact of rice production (PRODUKSI), gross domestic product (PDB), rice consumption (KONSUMSI), total population (PENDUDUK) of Indonesian citizens from 2014 to 2018 is 84,734 within signification level of 0,000 . This will open the possibility for smaller signification model level which is 0,05 . Thus, applied regression model could be used to predict imported rice volume.

Table 4

Result if $\mathrm{R}^{2}$

\begin{tabular}{|l|l|l|l|l|}
\hline Model & R & R Square & Adjusted R Square & Std. Error of the Estimate \\
\hline 1 & $.820^{\mathrm{a}}$ & .673 & .665 & 3260984.51910 \\
\hline
\end{tabular}

Source: Processed data by researcher

a. Predictors: (Constant), Inhabitant, Consumption, PDB, Production. 
Result of R2 displayed in table 4 indicates the impact of rice production (Production), gross domestic product (PDB), rice consumption (Consumption), total population (Inhabitant) of Indonesian citizens from toward imported rice volume (Import) from 2014 to 2018 is 0,673 . The value means that the impact of rice production (Production), gross domestic product (PDB), rice consumption (Consumption), total population (Inhabitant) of Indonesian citizens from toward imported rice volume (Import) is 67,3\%. Meanwhile, the rest $32,7 \%$ is affected by other variables that will be completed in future research.

Table 5

Regression result

\begin{tabular}{|c|c|c|c|c|c|}
\hline \multirow[t]{2}{*}{ Model } & \multicolumn{2}{|c|}{ Unstandardized Coefficients } & Standardized Coefficients & \multirow[t]{2}{*}{$\mathrm{t}$} & \multirow[t]{2}{*}{ Sig. } \\
\hline & $\mathrm{B}$ & Std. Error & Beta & & \\
\hline (Constant) & 104725.098 & 491474.594 & & .213 & .832 \\
\hline Production & .238 & .239 & .144 & .997 & .320 \\
\hline 1 PDB & 1.188 & .832 & .113 & 1.428 & .155 \\
\hline Consumption & -2041.783 & 3555.034 & -.026 & -.574 & .567 \\
\hline Ihabitant & 310.806 & 92.757 & .593 & 3.351 & .001 \\
\hline
\end{tabular}

a. Dependent Variable: Import

Equation models used to test hypothesis 1 to 4 are displayed in table 5 .

Hypothesis 1 stated that rice production (Production) gives impact toward rice import volume (Import). The result of analysis revealed that there is positive impact of rice production toward rice import volume as much as 0,238 within $p$ value of 0,320 . According to the explanation, it is concluded that $\mathrm{H} 1$ is rejected that stated rice production (Consumption) has no impact toward rice import volume (Import). Because, the imported rice performed by government is meant as future supply of Indonesia (Christianto, 2013). The volume of rice supply determined by government is $20 \%$ of total demand.

Hypothesis 2 stated that gross domestic product (PDB) gives impact toward rice import volume (Import). The result of analysis stated that there is positive impact of gross domestic product toward rice import volume as much as 1,188 within $p$ value of 0,155 . According to the explanation, it is concluded that $\mathrm{H} 2$ is rejected that stated gross domestic product (PDB) has no impact toward rice import volume (Import). The result is supported by previous study conducted by Rugswang and Victorio (2008), Yuniarti (2010), Kwanmas (2010).

Hypothesis 3 stated that rice consumption (Consumption) gives impact toward rice import volume (Import). The result of analysis revealed that there is negative impact of rice consumption toward rice import volume as much as $-2041,783$ within $p$ value of 0,567 . According to the explanation, it is concluded that $\mathrm{H} 3$ is rejected that stated rice consumption (Consumption) has no impact toward rice import volume (Import). The change of consumption pattern by society let this phenomenon to happen, they started to change into alternatives food such as oats or corns (Rachman, 2009). The result is contradicted with previous study conducted by Christianto (2013).

Hypothesis 4 stated that total population (Inhabitant) gives impact toward rice import volume (Import). The result of analysis revealed that there is positive impact of total population toward rice import volume as much as 310,806 within $p$ value of 0,001 . According to the explanation, it is concluded that $\mathrm{H} 4$ is accepted that stated total population (Inhabitant) has impact toward rice import volume (Import). The increasing demand is determined by increasing population of a country, which is why the demand for rice import is increasing. This result is supported by previous study conducted by Dwipayana and Kesumajaya (2014).

\section{Conclusion}

Based on the revealed finding and discussion above it could be show that Rice production (Production), gross domestic product (PDB), rice consumption (Consumption) have no impact toward rice import volume in Indonesia from 2014 to 2018. Total population (Inhabitant) has impact toward rice import volume in Indonesia from 2014 to 2018.

\section{Suggestions}

1. Government must increase rice production volume by providing better support for agriculture sector and increase development in that sector, also the volume of imported rice must be equals to people demand.

2. The future research should add more varieties of variables that can affect imported rice volume and increase the data of research.

\section{VI.References}

National statistic center board (BPS). 2018. Data Strategis BPS. Jakarta.

Bulog. 2018. Jakarta.

Christianto. 2013. Faktor Yang Mempengaruhi Volume Impor Beras di Indonesi. Jurnal JIBEKA Volume 7 No 2 Agustus 2013. 
Djunaedi, A. 2012. Analisis Faktor-Faktor yang Mempengaruhi Konsumsi Beras di Indonesia periode 2001-2010. Skripsi. Malang. Universitas Ma Chung.

Dwipayana and Kesumajaya. 2014. Pengaruh Harga, Cadangan Devisa, Dan Jumlah Penduduk Terhadap Impor Beras Indonesia periode 1997-2012, E-Jurnal Ekonomi pembangunan Universitas Udaya Vol. 3, No. 4, April 2014.

Greco. A. 2005. Cross Elasticity of Supply: Seldom Heard of and Seldom Taught. Journal for Economic Educators. Vol. 5 No. 1.

Hanani, H. 2012. Penguatan Ketahanan Pangan di Wilayah ASEAN Sebagai Strategi Menghapuskan Kemiskinan dan Kelaparan. E-Journal Ekonomi Pertanian. Vol 1, No. 1.

Juniantara, I Putu Kusuma dan Budhi, Made Kembar Sri. Pengaruh Ekspor, Impor Dan Kurs Terhadap Cadangan Devisa Nasional Periode 1999-2010 (Jurnal Ekonomi Pembangunan) November 2012, No 1, Vol 1.

Kwanmas. 2010. The Analysis of Affecting Imports of Rice Indonesia. Jurnal Internasional, Volume No. 3. No. 1 March 2010.

Larassati, H. 2007. Analisis Faktor-Faktor Yang Mempegaruhi Volume Impor Komoditas Keramik di Indonesia. Skripsi. Bogor. Institut Pertanian Bogor.

Mallios, Seth and Shane Emmet. 2004. Demand, Supply, and Elasticity in The Copper Trade at Early Jamestown. The Journal of The Jamestown Rediscovery Center Vol. 2.

Mankiw, N. Gregory. 2008. Principles of Macroeconomics Fifth Edition. Mason (USA): South-Western Cengage Learning.

Pakpahan, Asima Ronitua Samosir. 2012. Analisis Faktor yang Mempengaruhi Impor Daging Sapi di Indonesia. Economic Development Analysis Journal, 1 (2), pp: 1-4.

Krugman, Paul R. dan Obstfeld, Maurice. 2000, Ekonomi Internasional Teori dan Kebijaksanaan, Jakarta: Rajawali Press.

Prabowo, R. 2010. Kebijakan Pemerintah Dalam Mewujudkan Ketahanan Pangan Di Indonesia Rossi Prabowo Staf Pengajar Fakultas Pertanian Universitas Wahid Hasyim Semarang. Mediagro, 6(2).

Rachman, H. P. S. 2009. Impact of Food-Energy-Financial ( PEF ) Crisis on the Performance of National Food Security, 107-121.

Rungswang \& Victorio. 2008. The Effect of a Free-Trade Agreementupon Agricultural Imports, Jurnal Internasional. Wellington: Victoria University. Bangkok: Chulalongkorn University.

Salvatore, D. 2004, International Economics, Eight Edition, Wiley.

Singgih, V. A. 2015. Pengaruh Produksi, Jumlah Penduduk, PDB dan Kurs Dollar Terhadap Impor Jagung Indoneia. E-Jurnal EP Unud Vol 4 (2), Universitas Udayana.

Yuniarti. 2010. Agreement on Agriculture and Indonesian Rice Import”. Economics Journal of Emerging Market, Universitas Islam Indonesia, Department of Economics, vol. 2(3). 